
RESEARCH AND DEVELOPMENT

\author{
http://journal.unnes.ac.id/sju/index.php/higeia
}

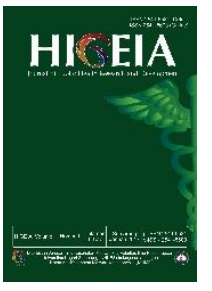

\title{
Pengetahuan Pengaruhi Sikap dan Tindakan Mahasiswa terhadap Program Pencegahan Thalassemia di Indonesia
}

\author{
Yanuarita Tursinawati $^{1 凶}$, Wijayanti Fuad ${ }^{1}$ \\ ${ }^{1}$ Fakultas Kedokteran, Universitas Muhammadiyah Semarang, Indonesia
}

\begin{abstract}
Info Artikel
Abstrak

Sejarah Artikel:

Diterima 3 September

2018

Disetujui 18 Oktober 2018

Dipublikasikan 30

Oktober 2018

Keywords:

Knowledge, Attitudes,

Practice, Thalassemia

DOI:

https://doi.org/10.15294

/higeia.v2i4.25407

Pengetahuan, sikap dan tindakan yang baik oleh tenaga kesehatan seperti dokter dalam upaya strategi pencegahan thalassemia sangat diperlukan, karena dokter yang berperan sebagai penyampai informasi kepada masyarakat. Penelitian ini bertujuan untuk mengetahui tingkat pengetahuan, sikap dan tindakan mahasiswa kedokteran tentang pencegahan thalassemia. Penelitian dengan pendekatan cross sectional study ini melibatkan 96 mahasiswa angkatan tahun I s.d IV, di Fakultas Kedokteran, Universitas Muhammadiyah Semarang antara bulan April-Juni 2018. Analisis pengetahuan, sikap, tindakan terhadap thalasemia menggunakan kuesioner. Skor tiap angkatan dibandingkan dengan uji Kruskal wallis, hubungan antara skor sikap, tindakan dengan pengetahuan diuji dengan regresi linier sederhana. Sebanyak $42,7 \%$ mahasiswa memiliki pengetahuan yang baik, mayoritas memiliki sikap yang positif $(72,9 \%)$, tindakan yang baik (91,7\%). Sebagian besar $(70,8 \%)$ memiliki rencana untuk memeriksakan status karier thalassemia, namun lebih memilih menunda pemeriksaan sampai saat akan menikah $(58,3 \%)$. Terdapat hubungan yang signifikan $(\mathrm{P}=0,023)$ antara sikap dengan pengetahuan dan antara tindakan dengan pengetahuan $(p=0,039)$. Mahasiswa memiliki pengetahuan, sikap dan tindakan yang baik tentang pencegahan thalassemia serta tingkat pengetahuan mempengaruhi sikap dan tindakan mahasiswa.
\end{abstract}

\begin{abstract}
Adequate knowledge, attitudes and practice by health workers such as doctors in thalassemia prevention strategies are needed, because doctors as informers to the public. This study aims to determine knowledge, attitudes and practice of medical students about thalassemia. This study was a cross sectional study involving 96 students from grade year I to IV, at the Faculty of Medicine, University of Muhammadiyah Semarang between April-June 2018. Analysis of knowledge, attitudes, practice against thalassemia used a questionnaire. The score of each grade was compared using Kruskal Wallis, relationship between attitude, practice with knowledge was analyzed with simple linear regression. A total of $42.7 \%$ of students had good knowledge, the majority had a positive attitude (72.9\%), good practice (91.7\%). Most (70.8\%) had plans to check thalassemia career status, but prefered to postpone until get married (58.3\%). There was a significant relationship ( $p=$ $0.023)$ between attitudes with knowledge and between practice with knowledge $(p=0.039)$. Students have good knowledge, attitudes and practice and level of knowledge influences their attitudes and practice.
\end{abstract}

(C) 2018 Universitas Negeri Semarang

Alamat korespondensi:

Gedung Fakultas Kedokteran Unimus

p ISSN 1475-362846

J1.Kedungmundu Raya no.18, Semarang

e ISSN 1475-222656

E-mail: vanuarita tursina@unimus.ac.id 


\section{PENDAHULUAN}

Thalasemia yang merupakan kelainan hemoglobinopati masih menjadi masalah kesehatan di Indonesia. Thalasemia adalah kelainan herediter bersifa autosomal resesif yang diakibatkan oleh berkurangnya sintesis salah satu rantai globin akibat mutasi gen globin. Thalassemia diklasifikasikan menjadi thalassemia alfa dan beta berdasarkan pada penurunan dan kerusakan rantai globinnya. Jumlah pembawa sifat thalasemia di Indonesia masih tinggi dengan 3-20\% pembawa sifat $\alpha$ thalassemia, $3 \%$ pembawa sifat $\beta$ thalassemia dan $1-33 \%$ pembawa sifat $\mathrm{HbE}$ yang merupakan salah satu variasi hemoglobinopati yang lain (Viprakasit, 2009). Tanda dan gejala klinis pasien thalasemia bergantung pada derajat yang dibedakan atas thalassemia minor, intermediat dan mayor. Tanda dan gejala dapat berupa anemia dengan berbagai derajat keparahan, hepatosplenomegali, gagal jantung kongestif, dan gagal tumbuh pada pasien thalasemia anak (Origa, 2010). Pasien thalassemia juga mengalami kelainan tulang yang disebabkan karena hiperplasia sumsum tulang terutama pada tulang wajah dan tengkorak.

Pasien thalasemia mayor ditandai dengan anemia hemolitik berat yang membutuhkan tranfusi darah berulang dan terapi khelasi besi (Colah, 2004). Penderita thalasemia sampai saat ini belum ada obat yang dapat menyembuhkan secara total. Pengobatan yang dilakukan meliputi pengobatan terhadap penyakit dan komplikasinya. Pengobatan terhadap penyakit dengan cara tranfusi darah, splenektomi, dan transplantasi sumsum tulang. Transfusi darah memiliki beberapa resiko diantaranya adalah penularan infeksi seperti Hepatitis B,HIV juga yang paling berat akibat transfusi darah adalah akumulasi besi (overload besi sekunder) yang dapat menumpuk dan merusak organ seperti pada hati, jantung, pankreas dan tiroid. Keadaan ini dapat meningkatkan angka mortalitas dan morbiditas pasien thalasemia, oleh karena itu diperlukan terapi khelasi besi. Namun, terapi transfusi dan khelasi besi yang dijalani pasien thalasemia memerlukan biaya yang besar dan beban psikologis baik bagi penderitanya sendiri maupun bagi keluarganya.

Mengingat permasalahan tersebut diatas, maka sangatlah penting untuk menurunkan angka kelahiran bayi dengan thalasemia dengan cara strategi pencegahan primer. Pencegahan primer terhadap kejadian thalasemia dapat dilakukan baik secara prospektif atau secara retrospektif. Cara prospektif yakni dengan cara melakukan skrining masa misalnya pada sekolah, kantor atau instansi tertentu, sedangkan cara retrospektif melalui skrining pada keluarga pasien thalasemia (Giordano, 2009). Pencegahan thalassemia juga dapat dilakukan melalui premarital screening dan prenatal diagnosis (PND). Bagi negara Islam seperti Iran, aborsi merupakan hal illegal, oleh karena itu pencegahan thalassemia melalui premarital screening. Program pencegahan lainnya di Iran melalui 4 strategi yakni edukasi masyarakat, skrining pasangan yang akan menikah, konseling genetik dan PND (Karimi et al., 2007). Premarital screening dilakukan baik secara retrospektif maupun prospektif. Retrospektif strategi dilakukan dengan melibatkan keluarga dengan status karier yang akan menikah melalui konseling pranikah. Prospektif dilakukan dengan melibatkan pasangan yang tercatat pada Kantor Pernikahan di India untuk mendapatkan sertifikat premarital screening. Pasangan akan menjalani pemeriksaan laboratorium darah,jika hasil pemeriksaan kadar Mean Corpuscular Haemoglobin $(\mathrm{MCH}) \geq 27$ pg dan Mean Corpuscular Volume (MCV) $\geq 80 \mathrm{fL}$, maka sertifikat baru diberikan (Karimi, 2007). Jika kadar kurang dari standar tersebut, pasangan akan melanjutkan pemeriksaan untuk memeriksa kadar Hemoglobin HbA2. Jika seseorang dengan $\mathrm{HbA} 2 \quad 3,5 \quad-7 \quad \%$ dicurigai sebagai karier dan dilakukan konseling genetik. Beberapa pilihan diberikan untuk mebatalkan pernikaha atau melanjutkan pernikahan tetapi disarankan untuk memiliki anak atau jika hamil dilakukan prenatal screening dan aborsi jika terbukti anak menderita thalassemia. Hal ini dilakukan di Iran sekitar tahun 2002. PND dilakukan melalui dua cara yakni Chorionic Villus Sampling (CVS) saat usia kandungan 10- 
14 minggu dan amniosintesis saat usia kandungan 15-17 minggu (Yang, 2016). CVS dilakukan dengan mengambil villi, sedangkan amniosintesis dengan megambil cairan amnion dengan panduan ultrasonografi untuk kemudian sampel dilakukan pemeriksaan molekuler DNA. Program pencegahan tersebut juga dilakukan di negara lain dan terbukti sukses menurunkan insiden thalasemia di Italia, Yunani dan Siprus. Kesuksesan program pencegahan ini di Siprus ditunjukkan dengan hanya ditemukannya lima bayi thalasemia lahir antara tahun 1991 sampai 2001 (Bozkurt, 2007).

Kesuksesan progam pencegahan thalasemia memerlukan tiga elemen penting, yakni informasi, kampanye skrining dan genetik konseling yang terorganisir. Bahkan di Siprus, penduduk mendapatkan informasi yang lengkap tentang thalasemia sejak di bangku sekolah sebagai kampanye program preventif (Kalokairinou, 2007). Beberapa penelitian membuktikan bahwa masyarakat yang teredukasi dengan baik akan meningkatkan kesadaran mereka tentang thalasemia dan bahaya dari penyakit tersebut (Wong, 2011a). Penyampaian informasi tentang masalah kesehatan ini menjadi tanggungjawab tenaga kesehatan, terutama dokter. Dokter seharusnya memiliki pengetahuan yang memadai tentang thalasemia saat melakukan konseling dengan pasien dan keluarganya. Penelitian oleh Emdadul (2015) menemukan bahwa rata rata skor pengetahuan responden mahasiswa kedokteran di Malaysia lebih rendah dibandingkan dengan mahasiswa keperawatan dan farmasi. Idealnya mahasiswa memiliki pengetahuan yang tinggi mengingat mahasiswa kedokteranlah yang diharapkan dapat menjadi pionir dalam masyarakat atau dalam lingkup keluarganya untuk memiliki kesadaran dalam memeriksakan dirinya sebagai upaya skrining thalasemia. Penelitian di Indonesia oleh Dewanto (2016) yang mengidentifikasi pengetahuan, sikap dan tindakan mahasiswa kedokteran tahun pertama membuktikan bahwa semakin tinggi pengetahuan mahasiswa kedokteran maka semakin tinggi pula keinginan mereka untuk menjalani skrining thalassemia.
Penelitian yang menganalisis pengetahuan, sikap dan tindakan mahasiswa kedokteran untuk setiap tingkatan tahun belum pernah dilakukan. Oleh karena itu, penelitian ini bertujuan untuk mengetahui tingkat pengetahuan, sikap dan tindakan mahasiswa kedokteran tiap angkatan tahun tentang thalassemia yang nantinya berdampak pada penyampaian informasi kepada masyarakat.

\section{METODE}

Penelitian ini merupakan penelitian observasional analitik dengan pendekatan cross sectional study. Penelitian ini melibatkan 96 responden mahasiswa angkatan tahun I, II, III dan IV di Fakultas Kedokteran, Universitas Muhammadiyah Semarang (Unimus) antara bulan April-Juni 2018. Teknik sampling yang digunakan pada penelitian ini adalah stratified random sampling untuk setiap angkatan. Variabel terikat yang diteliti dalam penelitian ini adalah sikap dan tindakan mahasiswa Fakultas Kedokteran, Unimus sedangkan variabel bebasnya adalah tingkat pengetahuan. Etika dalam penelitian ini dinyatakan dengan ethical clearance yang dikeluarkan oleh komisi etik Fakultas Kedokteran Universitas Muhammadiyah Semarang.

Sumber data dalam penelitian ini adalah data primer yang diperoleh dengan teknik pengambilan data berupa wawancara langsung menggunakan kuesioner pada responden. Responden sebelumnya telah diberikan penjelasan mengenai maksud dan tujuan penelitian serta telah menyetujui dengan cara menandatangani informed consent. Responden yang bersedia terlibat tanpa keterpaksaan dalam penelitian akan dianalisis tingkat pengetahuan, sikap, tindakan terhadap thalasemia melalui kuesioner yang terstruktur. Kuesioner terdiri dari 5 bagian, yakni identitas responden, pengetahuan, sikap, tindakan terhadap thalasemia dan waktu pemeriksaan status thalasemia. Pada bagian identitas menganalisi umur, jenis kelamin, etnis, asal kelahiran, perkawinan sedarah dalam keluarga dan status perkawinan. Kuesioner tentang pengetahuan 
dan sikap diambil dari penelitian yang telah digunakan oleh penelitian sebelumnya kemudian ditranslate dalam bahasa Indonesia (Pujani, 2017). Bagian pengetahuan terdiri dari 15 pertanyaan dimana 9 pertanyaan memerlukan jawaban berupa "Ya", "Tidak" dan "Tidak Tahu". Pertanyaan tentang pengetahuan melputi pengetahuan umum tentang, pewarisan thalassemia, diagnosis thalassemia, pengobatan thalassemia dan pencegahan thalasemia. Setiap jawaban benar akan diberi nilai 1 , sehingga maksimum skor adalah 15. Skor akan dikelompokkan menjadi pengetahuan sangat baik (13-15), baik (10-12), cukup (7-9) dan buruk (<6). Pada bagian sikap, responden akan ditanyakan sebanyak 9 pertanyaan mengenai tanggapan/ reaksinya terhadap upaya pencegahan thalasemia melalui premarital screening dan prenatal screening serta kontribusinya terhadap pasien thalasemia dan dinyatakan dengan jawaban "Ya", "Tidak", "Tidak Tahu". Jawaban yang benar akan diberi skor 1, sehingga total skor 9. Skor akan dikelompokkan dengan sikap positif jika skor $>5$ dan sikap negatif jika skor $<5$. Kuesioner tentang tindakan responden akan dianalisis dengan 9 pertanyaan yang berisi tentang tindakan responden jika dalam keluarga ada penderita, pernikahan sedarah dan menikah dengan carrier thalasemia seperti yang digunakan oleh (Basu, 2015). Selain itu juga ditanyakan tentang tindakan terhadap prenatal diagnosis dan terminasi kehamilan. Jawaban yang benar akan diberi skor 1,sehingga total skor 9. Skor akan dikelompokkan dengan tindakan baik jika skor $>5$ dan tindakan buruk jika skor $<5$. Responden juga ditanyakan tentang waktu dilaksanakannya pemeriksaan status thalasemia.

Data diuji normalitasnya dengan Kolmogorov Smirnov, karena distribusi data yang didapat tidak normal maka dilakukan uji nonparametrik Kruskal Wallis dilanjutkan dengan uji Mann-Whitney. Pengolahan data dilakukan dengan bantuan komputer menggunakan program komputer SPSS dengan batasan signifikasi $p \leq 0,05$ dan CI $95 \%$. Hubungan antara skor sikap dan tindakan dengan skor tingkat pengetahuan diuji dengan regresi linier sederhana.

\section{HASIL DAN PEMBAHASAN}

Penelitian yang melibatkan 96 responden mahasiswa Fakultas Kedokteran Unimus didapatkan mayoritas mahasiswa berada di tahun pertama pendidikan dokter $(30,2 \%)$, berumur $<20$ tahun $(62,5 \%)$, perempuan $(62,5 \%)$, etnis Jawa $(83,3 \%)$, berasal dari pedesaan $(54,2 \%)$ dan belum menikah $(93,8 \%)$ dan tidak ada riwayat perkawinan sedarah dalam keluarganya $(94,8)$.

Sebanyak 42,7 \% mahasiswa memiliki pengetahuan yang baik terkait program pencegahan thalassemia (tabel 1). Hal ini disebabkan para mahasiwa kedokteran Unimus tersebut mendapatkan mata kuliah thalassemia dalam kurikulum wajib sejak di tahun pertama masa studi. Selain itu mayoritas mahasiswa kedokteran berasal dari SMU dengan latar belakang bidang Ilmu Pengetahuan Alam dimana telah dikenalkan tentang ilmu biologi yang berkaitan dengan genetik dan penyakitnya meskipun dalam lingkup dasar. Hasil penelitian ini sejalan dengan penelitian oleh (Pujani, 2017) berjudul "Knowledge and attitude among indian medical student towrads thalassemia : a study in Delhi NCR" yang menganalisis pengetahuan dan sikap mahasiswa kedokteran tahun pertama dan kedua dimana hasilnya menunjukkan bahwa sebagian besar responden penelitiannya yakni sekitar 44,59\% mahasiswa kedokteran tahun pertama dan $52,17 \%$ mahasiswa kedokteran tahun kedua memiliki tingkat pengetahuan yang baik. Saat lulus nantinya mahasiswa kedokteran inilah yang menjadi dokter sebagai sumber informasi thalasemia di masyarakat. Penelitian oleh Chatterjee (2016) yang melibatkan dokter muda sebagai respondenya menunjukkan bahwa pengetahuan responden tersebut memiliki tingkat yang baik terhdap thalassemia. Dokter seharusnya memiliki pengetahuan yang memadai tentang thalasemia saat melakukan konseling dengan pasien dan keluarganya. Pengetahuan tersebut hendaknya sudah dimiliki sejak masih dalam 
bangku perkuliahan saat menjadi mahasiswa kedokteran. Namun berbeda dengan yang ditemukan pada penelitian oleh Seyam (2010) dimana mayoritas mahasiswa memiliki tingkat pengetahuan yang rendah terhadap thalassemia.

Penelitian ini menganalisa sikap mahasiswa kedokteran dengan menanyakan sikap mereka terhadap pencegahan melalui skrining pranikah, kesediaan menjadi donor darah dan sumsum tulang dan upaya pencegahan thalassemia lainnya. Hasil penelitian ini menunjukkan bahwa sebagian besar $(72,9 \%)$ mahasiswa memiliki sikap positif terhadap upaya pencegahan thalasemia seperti yang tercantum pada tabel 1. Pada bagian sikap, responden memberikan tanggapan dan reaksinya terhadap upaya pencegahan thalasemia melalui premarital screening dan prenatal screening serta kontribusinya terhadap pasien thalasemia misalnya dalam hal donor darah ataupun donor transplantasi sumsum tulang. Penelitian oleh Emdadul (2015) yang membandingkan sikap mahasiswa dalam bidang kesehatan yakni kedokteran, keperawatan dan farmasi. Hasilnya menunjukkan bahwa rata-rata skor sikap mahasiswa keperawatan sama dengan mahasiwa kedokteran dan lebih baik dibandingkan mahasiswa farmasi. Meskipun dalam klasifikasi mahasiswa kedokteran Malaysia tersebut masuk dalam skor sikap yang kurang.

Tindakan memiliki arti melaksanakan atau mempraktikkan apa yang diketahui atau yang disikapinya yang dinilai baik (Notoatmodjo S, 2012). Tindakan dalam penelitian ini menganalisis praktik responden tentang keinginan untuk melakukan pernikahan sedarah, konseling pranikah untuk dirinya sendiri dan keluarganya, prenatal diagnosis (PND), terminasi kehamilan, donor darah dan tindakan pencegahan thalassemia yang lainnya. Hasil menunjukkan bahwa mayoritas $(91,7 \%$.) responden memiliki tindakan yang baik terhadap upaya pencegahan thalassemia. Prenatal diagnosis menjadi salah satu poin pertanyaan yang berkaitan dengan tindakan pencegahan, meskipun di Indonesia secara agama keberlanjutan hasil PND, yakni terminasi janin yang menderita kelainan genetik masih menjadi perdebatan. Secara hukum, aborsi hanya diperbolehkan pada kehamilan yang membahayakan ibu baik secara fisik dan mental. Oleh karena itu,jika tindakan pencegahan thalassemia akan dilakukan pada masyarakat melalui pemeriksaan status karier, premarital screening dan PND makan harus mempertimbangkan segi agama, hukum dan budaya (Wong, 2011b).

Parameter tindakan dibuktikan dengan banyaknya responden yang memiliki rencana melakukan pemeriksaan status karier mereka yakni sebanyak 70,8 \%, meskipun waktunya, sebagian besar lebih memilih menunda sampai saat akan menikah (58,3\%) seperti yang tercantum pada tabel 2. Presentase responden yang memiliki keinginan untuk melakukan pemeriksaan status karier lebih rendah dibandingkan dengan responden mahasiswa kedokteran pada penelitian Dewanto (2016) yang mencapai angka 95,6\%. Pada penelitian tersebut, waktu yang dipilih responden untuk

Tabel 1. Tingkat pengetahuan, sikap dan tindakan responden terhadap pencegahan thalassemia

\begin{tabular}{lcc}
\hline Variabel & $\begin{array}{c}\text { Frekuensi } \\
\text { Persentase } \\
(\%)\end{array}$ \\
\hline Tingkat Pengetahuan & 11 & 11,5 \\
$\quad$ Buruk & 40 & 41,7 \\
$\quad$ Cukup & 41 & 42,7 \\
$\quad$ Baik & 4 & 4,2 \\
$\quad$ Sangat baik & 26 & 27,1 \\
Sikap & 70 & 72,9 \\
$\quad$ Negatif & & \\
$\quad$ Positif & 8 & 8,3 \\
Tindakan & 88 & 91,7 \\
$\quad$ Buruk & & \\
$\quad$ Baik & 12 & 12,5 \\
Rencana Periksa status & 16 & 16,7 \\
karier & 68 & 70,8 \\
$\quad$ Tidak tahu & & \\
$\quad$ Tidak & \\
$\quad$ Ya & & \\
Waktu Periksa status & 58,3 \\
Karier & \\
$\quad$ Nanti saat akan & 56 & 12,5 \\
$\quad$ menikah & & \\
$\quad$ Segera setelah & 12 & \\
$\quad$ wawancara & &
\end{tabular}


memeriksaan status kariernya bervariasi, yakni $40,6 \%$ saat hendak menikah, 39,4\% setelah mengisi kuesioner penelitian dan sisanya $20 \%$ akan melakukan pemeriksaan di waktu yang akan datang. Upaya menumbuhkan kesadaran dalam rangka pemeriksaan status karier harus dirintis terutama bagi mahasiswa kedokteran yang nantinya menjadi pelayan kesehatan.

Pada tabel 2 terbukti bahwa tidak terdapat hubungan yang signifikan antara umur, jenis kelamin, etnis, asal kelahiran, dan adanya perkawainan sedarah dalam keluarga dengan tingkat pengetahuan, sikap dan tindakan. Hasil penelitian ini ternyata sejalan dengan hasil penelitian oleh Pujani (2017) yang menunjukkan bahwa tidak terdapat pengaruh antara usia, jenis kelamin dan asal kelahiran dengan skor pengetahuan serta sikap mahasiswa kedokteran baik pada tahun pertama maupun pada tahun kedua. Menurut Rubandiyah (2018) dinyatakan bahwa pengetahuan seseorang dipengaruhi oleh umur seseorang. Semakin bertambahnya umur sseorang maka pengetahuannya juga semakin bertambah. Penelitian ini berbeda dengan hasil penelitian oleh Vasudeva (2015) yang menganalisis pengetahuan dan partisipasi mahasiswa kedokteran dan non kedokteran terhadap program pencegahan thalassemia. Hasil penelitian tersebut membuktikan bahwa ras sangat berpengaruh secara signifikan terhadap pencegahan thalassemia, megingat ras dalam penelitian tersebut terbagi atas ras Malay, China, India dan ras laiinya. Hal ini berbeda dengan pengklasifikasian dengan penelitian ini. Hasil penelitian ini yang menganalisis hubungan antara umur dan sikap juga berbeda dengan hasil penelitian oleh Emdadul (2015) dimana dalam penelitian tersebut menemukan adanya korelasi positif antara umur dan sikap.

Status perkawinan seseorang tidak berpengaruh terhadap pengetahuan dan sikap responden pada penelitian in. Hal ini tidak sejalan dengan penelitian oleh Sulaiman (2018) yang melibatkan mahasiswa fakultas kesehatan di salah satu Universitas di Malaysia membuktikan bahwa terhadap hubungan yang signifikan antara status perkawinan dengan pengetahuan terhadap prenatal screening penyakit genetik seperti thalassemia, Down Syndrome dan Neural Tube Defect. Responden yang sudah menikah mampu mencari informasi yang lebih banyak tentang penyakit genetik tersebut dibandingkan dengan yang belum meikah. Hal inilah yang menyebabkan tingkat pengetahuan responden yang telah menikah lebih tinggi. Seorang yang sudah menikah juga mempengaruhi sikap mereka terhadap prenatal diagnosis seperti yang dibuktikan oleh penelitian Adekanbi (2014). Hasil penelitian ini membuktikan adanya hubungan yang signifikan antara tindakan mahasiswa yang berkaitan dengan pencegahan thalassemia dengan status perkawinan responden. Hasil penelitian oleh AlFarsi (2014) yang berjudul "A study on knowledge, attitude, and practice towards premarital carrier screening among adults attending primary healthcare centers in a region in Oman" sejalan dengan hasil penelitian ini, yakni status perkawinan responden berhubungan signifikan dengan tindakan responden untuk menjalani Premarital Carrier Screening (PMCS) terhadap penyakit genetik. Responden yang belum menikah tidak memiliki keinginan untuk menjalani PCMS. Pentingnya PCMS dirasa belum terlalu penting

Tabel 2. Hubungan Identitas responden dengan tingkat pengetahuan, sikap dan tindakan terhadap thalassemia

\begin{tabular}{lccc}
\hline \multicolumn{1}{c}{ Variabel } & NIlai $p$ value & \\
& Pengetahuan & Sikap & Tindakan \\
\hline Umur & 0,195 & 0,192 & 1 \\
Jenis Kelamin & 0,134 & 0,192 & 1 \\
Etnis & 0,083 & 0,92 & 0,762 \\
Asal Kelahiran & 0,924 & 0,155 & 0,621 \\
Perkawinan sedarah dalam keluarga & 0,904 & 0,162 & 0,489 \\
Status perkawinan & 0,756 & 0,722 & 0,022 \\
\hline
\end{tabular}


dan masih menjadi hal yang waktunya masih panjang untuk dihadapi bagi seorang yang belum menikah.

Pada tabel 3 menunjukkan adanya perbedaan yang signifikan antar angkatan mahasiswa pada tingkat pengetahuannya, yakni dengan $\mathrm{p}=0,005$. Sedangkan pada sikap dan tindakan tidak ditemukan adanya perbedaan yang signifikan dengan $p$ value masing masing 0,575 dan 0,483 . Perbedaan yang signifikan terlihat antar mahasiswa angkatan tahun pertama dan tahun ke $4(p=0,03)$ serta antar mahasiswa angkatan tahun pertama dan profesi koas $(\mathrm{p}=0,001)$ seperti yang tercantum pada tabel 4. Hal ini disebabkan karena meskipun mata kuliah thalassemia sudah diajarkan sejak tahun pertama namun hanya sebatas ilmu dasar kedokteran saja. Dalam kurikulum Fakultas Kedokteran Universitas Muhammadiyah Semarang blok 2 di semester pertama, tahun pertama yang membahas tentang biomolekuler dan dasar genetika hanya memberikan tentang prinsip biomolekuler termasuk bahasan tentang DNA/RNA dan pewarisan sifat menurut hukum Mendell. Sedangkan penyakit genetic seperti thalassemia diberikan dalam bentuk Problem Based Learning melalui diskusi kasus, Karena nantinya yang berkaitan dengan detail penyakit thalassemia akan diberikan pada tahun ke -3 yang berkaitan dengan ilmu Kedokteran Klinik. Terlebih pada mahasiswa profesi koas, mereka dituntut untuk menguasai daftar penyakit yang tercantum dalam Standar Kompetensi Dokter Indonesia (SKDI) tahun 2012, dimana lulusan dokter hendaknya menguasai keterampilan anamnesis dan konseling thalassemia dengan level kompetensi $4 \mathrm{~A}$, yakni mampu melakukan secara mandiri
(Konsil Kedokteran Indonesia, 2012). Oleh sebab itu dituntut untuk memiliki pengetahuan

Tabel 3. Skor dan perbandingan tingkat pengetahuan sikap dan tindakan responden

\begin{tabular}{lcc}
\hline Variabel & Mean \pm SD & $p$ value \\
\hline $\begin{array}{l}\text { Tingkat } \\
\text { pengetahuan }\end{array}$ & $9,17 \pm 2,24$ & 0,005 \\
Sikap & & \\
Tindakan & $6,34 \pm 1,30$ & 0,575 \\
& $7,51 \pm 1,26$ & 0,483 \\
\hline
\end{tabular}

yang lebih tinggi karena mahasiswa profesi koas adalah dokter muda yang akan segera terjun ke masyarakat. Bekal pengetahuan tentang thalassemia yang baik menjadi dasar dalam melakukan konseling sebagai upaya pencegahan thalassemia.

Terdapat hubungan yang signifikan $(\mathrm{P}=0,023)$ antara sikap dengan pengetahuan meskipun hubungannya lemah dengan nilai $\mathrm{R}=$ 0,203 seperti yang tercantum pada tabel 5 . Hal ini membuktikan bahwa sikap positif yang ditunjukkan oleh responden dalam studi ini didukung oleh tingkat pengetahuan yang baik. Menurut Azwar (2007) salah satu pembentuk sikap adalah komponen kognitif yang dalam hal ini diwujudkan dalam parameter tingkat pengetahuan responden. Hasil studi ini juga sejalan dengan penelitian Pujani (2017) dan Chatterjee (2016) yang membuktikan bahwa pengetahuan mahasiswa kedokteran tentang thalasemia berefek terhadap sikap baik yang ditunjukkan oleh responden. Hal ini dipertegas oleh hasil studi Emdadul (2015) berdasarkan analisis korelasi Perason bahwa terdapat korelasi positif antara pengetahuan dan sikap seseorang.

Hubungan yang lemah namun signifikan juga terjadi antara tindakan dengan pengetahuan $(p=0,039, R=0,181)$ seperti yang

Tabel 4. Perbandingan tingkat pengetahuan tiap angkatan

\begin{tabular}{llllll}
\hline & \multicolumn{5}{c}{ Mahasiswa angkatan } \\
\cline { 2 - 6 } & Tahun Pertama & Tahun ke 2 & Tahun ke 3 & Tahun Ke 4 & Profesi Koas \\
\cline { 2 - 6 } Tahun Pertama & - & 0,068 & 0,057 & 0,03 & 0,001 \\
Tahun Ke 2 & 0,068 & - & 0,792 & 0,131 & 0,158 \\
Tahun Ke 3 & 0,057 & 0,792 & - & 0,256 & 0,323 \\
Tahun Ke 4 & 0,003 & 0,131 & 0,256 & - & 0,821 \\
Profesi Koas & 0,001 & 0,158 & 0,323 & 0,821 & - \\
\hline
\end{tabular}


Tabel 5. Hubungan antara pengetahuan, sikap dan tindakan

\begin{tabular}{ccccc}
\hline Variabel & \multicolumn{3}{c}{ Sikap } & \multicolumn{2}{c}{ Tindakan } \\
\cline { 2 - 5 } Pengetahuan & $\mathrm{p}$ & $\mathrm{R}$ & $\mathrm{p}$ & $\mathrm{R}$ \\
\cline { 2 - 6 } & 0,023 & 0,203 & 0,039 & 0,181 \\
\hline
\end{tabular}

terbukti bahwa tindakan yang baik signifikan dipengaruhi oleh tingkat pengetahuan responden. Hal ini sejalan dengan penelitian Dewanto (2016) yang menganalisis waktu mahasiswa kedokteran dalam menentukan keikutsertaan pemeriksaan status kariernya. Studi tersebut menunjukkan bahwa semakin tinggi tingkat pengetahuan responden, maka semakin cepat responden memutuskan tindakan untuk memeriksakan status karier thalassemia. Meskipun dalam penelitian ini sebagian besar $(58,3 \%)$ lebih memilih akan memeriksakan status kariernya nanti saat akan menikah. Implementasi program mandatory premarital screening dan skrining pada wanita muda yang belum menikah terbukti menurunkan kelahiran bayi dengan thalassemia di beberapa negara di dunia seperti yang dibuktikan oleh Zlotogora (2009). Kendala yang sering dihadapi negara berkembang seperti Indonesia dalam program pencegahan thalassemia adalah biaya, mengingat pendekatan prospektif memerlukan biaya yang tinggi. Oleh karena itu dapat dimulai dengan melakukan premarital screening diantara keluarga pasien thalassemia sebagai upaya pencegahan thalassemia di Indonesia secara retrospektif yang dinilai lebih mudah dan murah dibandingkan upaya prospektif.

\section{PENUTUP}

Dari hasil penelitian, dapat disimpulkan bahwa sebanyak 42,7 \% mahasiswa memiliki pengetahuan yang baik, mayoritas memiliki sikap yang positif dan tindakan yang baik. Terdapat hubungan yang signifikan antara sikap dengan pengetahuan dan antara tindakan dengan pengetahuan, sehingga dapat disimpulkan tingkat pengetahuan mempengaruhi sikap dan tindakan mahasiswa.

Saran bagi peneliti selanjutnya adalah dengan menambah jumlah sampel, menambah variasi latar belakang pendidikan mahasiswa tenaga medis lainnya, dan menganalisis setiap poin pertanyaan pada kuesioner.

\section{DAFTAR PUSTAKA}

Adekanbi. 2014. The knowledge base and acceptability of prenatal diagnosis by pregnant women in Ibadan. Afr J Reprod Health, 18(1), $127-132$.

Al-Farsi, O. a, Al-Farsi, Y. M., Gupta, I., Ouhtit, A., Al-Farsi, K. S., \& Al-Adawi, S. 2014. A study on knowledge, attitude and screening among adults attending primary healthcare centers in a region in Omas. BMC Public Health, 14: 380.

Azwar S. 2007. Sikap Manusia Teori dan Pengukurannya. Yogyakarta: Pustaka Pelajar.

Basu, M. 2015. A study on knowledge, attitude and practice about thalassemia among general population in outpatient department at a Tertiary Care Hospital of Kolkata. Journal of Preventive Medicine and Holistic Health, 1(1): 613.

Bozkurt, G. 2007. Results from the North Cyprus Thalassemia Prevention Program. Hemoglobin, 31(2): 257-264.

Chatterjee, S., Mondal, T. K., Ahamed, A., Sarkar, I., \& Sarkar, K. 2016. Knowledge, Attitude, and Practice of Budding Doctors in Prevention of Thalassemia, 2(4): 18-24.

Colah, R., Nadkarni, A., Gorakshakar, A., Phanasgaonkar, S., Surve, R., Subramaniam, P. G., ... Mohanty, D. 2004. Impact of $\beta$ globin gene mutations on the clinical phenotype of $\beta$ thalassemia in India. Blood Cells, Molecules, and Diseases, 33(2): 153-157.

Dewanto, J. B., Tansah, H., Dewi, S. P., Napitu, H., Panigoro, R., \& Sahiratmadja, E. 2016. Increased knowledge of thalassemia promotes early carrier status examination among medical students. Universa Medicina, 34(3): 220.

Emdadul Haque, A. T. M., Puteh, F. A. B., Osman, N. L. B., Zain, Z. A. M., \& Haque, M. 2015. Thalassaemia: Level of awareness among the future health care providers of Malaysia. Journal of Chemical and Pharmaceutical Research, 7(2): 896-902. 
Giordano, P. C. 2009. Prospective and retrospective primary prevention of Hemoglobinopathies in multiethnic societies. Clinical Biochemistry, 42(18): 1757-1766.

Kalokairinou, E. M. 2007. The experience of betathalassaemia and its prevention in Cyprus. Medicine and Law, 26(2): 291-307.

Karimi, M., Jamalian, N., Yarmohammadi, H., Askarnejad, A., Afrasiabi, A., \& Hashemi, A. 2007. Options for Improving the Programme, 62-66.

Konsil Kedokteran Indonesia. 2012. Standar Kompetensi Dokter Indonesia 2012. Jakarta: Konsil Kedokteran Indonesia.

Notoatmodjo S. 2012. Promosi kesehatan dan Perilaku Kesehatan. Jakarta: Rineka Cipta.

Origa, R. G. and R. 2010. Beta-thalassemia, 1-15.

Pujani, M., Chauhan, V., Agarwal, C., Rana, D., Singh, K., \& Dixit, S. 2017. Knowledge and attitude among Indian medical students towards thalassemia: a study in Delhi NCR. International Journal of Research in Medical Sciences Int J Res Med Sci, 55(10): 4470-4477.

Rubandiyah, H. I. 2018. Pembentukan Kader Jumantik Sebagai Upaya Peningkatan Pengetahuan Siswa Di Sekolah Dasar. Higeia Journal of Public Health, 2(2): 216-226.

Seyam, S., \& Assemi, A. 2010. Study Of The Knowledge In Guilan University Students About Thalassemia. Journal of Urmia Nursing And Midwifery Faculty, 8(3): 0-0.

Sulaiman, N. S., \& Zainuddin, N. 2018. Knowledge and perception regarding prenatal genetic screening of thalassemia, down syndrome and neural tube defects: A study among iium Kuantan undergraduates. Malaysian Journal of Public Health Medicine, 18(1): 88-96.

Vasudeva Murthy, C. R., Zulkeflle, M. Z. A. Bin, Venkateswaran, S. P., \& Barua, A. 2015. Knowledge, awareness and participation of medical and non-medical students in the malaysia national thalassemia prevention programme. International Journal of Human Genetics, 15(2): 61-72.

Viprakasit, V., Lee-Lee, C., Chong, Q. T., Lin, K. H., \& Khuhapinant, A. 2009. Iron chelation therapy in the management of thalassemia: The Asian perspectives. International Journal of Hematology, 90(4): 435-445.

Wong, L. P., George, E., \& Tan, J. A. M. A. 2011. A holistic approach to education programs in thalassemia for a multi-ethnic population: Consideration of perspectives, attitudes, and perceived needs. Journal of Community Genetics, 2(2): 71-79

Wong, L. P., George, E., \& Tan, J. A. M. A. 2011. Public perceptions and attitudes toward thalassaemia: Influencing factors in a multiracial population. BMC Public Health, 11.

Yang, Y., He, P., \& Li, D. Z. 2016. Analysis of fetal blood: Is there still a role for prenatal diagnosis of thalassemia? Hemoglobin, 40(1): 29-31.

Zlotogora, J. 2009. Population programs for the detection of couples at risk for severe monogenic genetic diseases. Human Genetics, 126(2): 247-253. 